\title{
Analisis Miskonsepsi pada Mahasiswa Program Studi Matematika STKIP Harapan Bima
}

\author{
Rizcky Juliawan', Berti Mandala Putra ${ }^{2}$ \\ ${ }^{1,2}$ STKIP Harapan Bima \\ Email: ${ }^{1}$ risky.juliawan@gmail.com, ${ }^{2}$ bertimandalaputra.unj@gmail.com
}

\begin{abstract}
Misconception Analysis in Mathematics Education Department Student of STKIP Harapan Bima. This research is a descriptive qualitative research that aims to explore misconceptions in students and students' views about their misconceptions. The subject in this study were five students of Mathematics Department at STKIP Harapan Bima. Data collection techniques used in this study are tests and interviews. The test questions consist of geometry, probability theory, algebra, and calculus. Interviews were conducted to obtain information about students' views on the their misconceptions. The result of the research shows that in every mathematics material, students experience misconceptions. Overall, misconceptions are most common in geometric materials, but they are not significantly different from other materials. The type of misconception that is most often experienced by students is confusion because the do not master the supporting cocepts. The misconception that is most rarely experienced by students is wrong classification of concept examples.
\end{abstract}

Keywords: Misconceptions, Students, Mathematics.

\begin{abstract}
Abstrak
Penelitian ini merupakan penelitian kualitatif deskriptif yang bertujuan mengeksplorasi miskonsepsi pada mahasiswa serta pandangan mahasiswa mengenai miskonsepsi yang dialaminya. Subjek dalam penelitian ini yaitu lima mahasiwa Pendidikan Matematika di STKIP Harapan Bima. Teknik pengumpulan data yang digunakan dalam penelitian ini yaitu tes dan wawancara. Tes digunakan untuk menyelidiki miskonsepsi pada mahasiswa dalam menjawab soal. Soal tes terdiri dari materi geometri, teori peluang, aljabar, dan kalkulus. Wawancara dilakukan untuk memperoleh informasi mengenai pandangan mahasiswa terhadap miskonsepsi yang dialaminya. Hasil penelitian menunjukkan bahwa pada setiap materi matematika mahasiswa mengalami miskonsepsi. Secara keseluruhan miskonsepsi paling sering terjadi pada materi geometri, tetapi tidak berbeda secara signifikan dengan materi yang lain. Jenis miskonsepsi yang paling sering dialami mahasiswa yaitu kebingungan karena tidak menguasai konsep yang mendukung. Miskonsepsi yang paling jarang dialami mahasiswa yaitu klasifikasi yang salah terhadap contoh konsep.
\end{abstract}

Kata Kunci: miskonsepsi, mahasiswa, matematika.

\section{PENDAHULUAN}

Matematika mempunyai kontribusi substansial dalam pembangunan kehidupan manusia khususnya dalam penalaran pemecahan masalah (Mtetwa dkk., 2011). Dalam memecahkan masalah matematika, Ringkasan penelitian tidak lebih dari 500 kata yang berisi latar belakang penelitian, tujuan dan tahapan metode penelitian, luaran yang ditargetkan, serta uraian TKT penelitian yang diusulkan. Kata kunci maksimal 5 kata Latar belakang penelitian tidak lebih dari 500 kata yang berisi latar belakang dan permasalahan yang akan diteliti, tujuan khusus, dan urgensi penelitian. Pada bagian ini perlu dijelaskan uraian tentang spesifikasi khusus terkait dengan skema. siswa harus memahami konsep yang berkaitan dengan permasalahan tersebut (Woolfolk \& Margetts, 2013; Zahid \& Sujadi, 2017). Pembelajaran konsep sangat penting untuk diberikan dalam pembelajaran di sekolah pada setiap jenjang karena mendasari pembelajaran dan pembangunan kognitif (Senemoğlu, 2013).

Matematika adalah ilmu abstrak. Siswa akan sangat memahami teori abstrak ketika mereka memiliki pemahaman yang kuat tentang apa yang sedang diabstraksi (Gillian, 1990). Dalam memahami konsep abstrak tersebut, siswa membangun konsep matematika di kelas dan mengaitkannya dengan pengalaman hidup mereka (Campbell \& Campbell, 2008; Welder, 2012). Siswa harus mampu melakukan reorganisasi pengalaman mereka dalam bentuk matematis yang bersifat personal sehingga menjadikan siswa lebih mahir dan memahami bentuk kompleks yang abstrak (Ndemo \& Mtetwa, 2015).

Miskonsepsi matematika terjadi pada setiap jenjang pendidikan mulai dari pendidikan dasar, menengah hingga pendidikan tinggi 
(Ojose, 2015). Siswa masih mengalami kebingungan dalam beberapa konsep matematika (Roselizawati dkk., 2014). Miskonsepsi ini terjadi dalam berbagai cabang ilmu matematika misalnya aljabar, aritmatika, geometri, kalkulus dan peluang. Dalam aljabar miskonsepsi terjadi karena pemahaman siswa yang terbatas (Ndemo \& Mtetwa, 2015). Pada geometri siswa mengalami miskonsepsi dalam membedakan bangun jajargenjang, trapesium, belah ketupat, dan bangun sejenisnya (AlKhateeb, 2016). Siswa mengalami miskonsepsi dalam operasi pecahan (aritmatika) dan penjumlahan eksponen (aljabar) (Ojose, 2015). Miskonsepsi juga terjadi pada jenjang perguruan tinggi. Mahasiswa masih mengalami kesulitan karena kurangnya pemahaman konsep dari masalah atau kesulitan menghubungkan konsepkonsep matematika (Kharis dkk., 2018). Mahasiswa juga masih mengalami kesalahan pada konsep peluang (Astuty, 2015). Mahasiswa juga tidak tahu bagaimana mengaplikasikan transformasi rotasi. Mahasiswa memahami perhitungan aljabarnya tapi tidak memahami makna dari transformasi itu sendiri (Winarso \& Toheri, 2017). Miskonsepsi terjadi bukan hanya pada siswa tetapi juga pada guru. Miskonsepsi yang terjadi pada guru yaitu: (1) Miskonsepsi pada konsep bilangan, (2) Miskonsepsi pada urutan operasi, (3) Miskonsepsi pada pecahan, (4) Miskonsepsi pada indeks, (5) Kesalahan akibat lemahnya penguasaan kosa kata teknis, dan (6) Miskonsepsi pada aljabar (Naseer, 2015).

Fakta bahwa masih terdapat miskonsepsi pada mahasiswa dan guru menjadi suatu kekhawatiran dalam pembelajaran matematika. Akan sangat berbahaya jika siswa pindah dari satu jenjang ke jenjang berikutnya dengan miskonsepsi yang salah tersebut (Ojose, 2015). Ketika siswa mengalami miskonsepsi sejak awal, maka akan terjadi lagi miskonsepsi yang lebih besar pada jenjang berikutnya (Roselizawati dkk., 2014). Kesalahan dan miskonsepsi apabila sudah tertanam dalam memori siswa akan sulit dihilangkan (Sarwadi \& Shahrill, 2014; Svandova, 2014). Sulit untuk menghilangkan miskonsepsi, tetapi wajib bagi guru untuk mengetahui mengapa siswa melakukan kesalahan agar kesalahan tersebut tidak terjadi lagi (Ndemo \& Mtetwa, 2015).

Banyak penelitian yang mengungkapkan miskonsepsi dan kesalahan siswa dalam matematika (Biber et al., 2013; C. S \& S.M, 2018; Mohyuddin \& Khalil, 2016; Ozerem, 2012; Rakes, 2010; T \& E.C.M, 2019). Penelitian ini akan meneliti miskonsepsi pada mahasiswa ditinjau dari berbagai cabang ilmu matematika yaitu aljabar, aritmatika, geometri, dan peluang. Rumusan masalah yang diangkat dalam penelitian ini yaitu sebagai berikut: (1) Bagaimana mahasiswa memandang miskonsepsi pada matematika?, (2) Apa saja miskonsepsi mahasiswa dalam matematika?. Tujuan penelitian ini yaitu sebagai berikut: (1) Mengeksplorasi pandangan mahasiswa terhadap miskonsepsi pada matematika, Mengeksplorasi apa saja miskonsepsi mahasiswa dalam matematika.

\section{METODE}

Penelitian ini merupakan penelitian kualitatif deskriptif yang bertujuan mengeksplorasi miskonsepsi matematika pada mahasiswa serta pandangan mereka tentang miskonsepsi yang dialaminya. Miskonsepsi pada penelitian ini diperoleh dari hasil tes dan wawancara. Tes dilakukan untuk mengungkap bagaimana miskonsepsi yang terjadi pada mahasiswa. Soal tes terdiri dari empat materi inti matematika yaitu geometri, teori peluang, aljabar dan kalkulus. Masing-masing materi tersebut terdiri dari tiga soal uraian. Total soal tes yang diberikan yaitu duabelas soal. Selain tes, wawancara juga dilakukan untuk memperoleh data mengenai pandangan mahasiswa terhadap miskonsepsi yang dialaminya.

Penelitian ini meninjau miskonsepsi berdasarkan indikator miskonsepsi dari Rochmad dkk. (2018). Miskonsepsi tersebut terdiri dari : (1) konsep definsi yang tidak benar; (2) kesalahan penggunaan konsep; klasifikasi yang salah terhadap contoh konsep; (4) kekeliruan interpretasi konsep dengan makna konsep, (5) kebingungan karena tidak menguasai konsep yang mendukung, dan (6) penghubungan konsep yang salah. Berikut 
adalah rekapitulasi terjadinya miskonsepsi dalam menjawab soal tes yang diberikan.

\begin{tabular}{|c|c|c|c|c|c|c|c|c|c|c|c|c|}
\hline \multirow{4}{*}{ Subjek } & \multicolumn{12}{|c|}{ Tabel 1. Rekapitulasi Miskonsepsi dalam Menjawab Soal Tes } \\
\hline & \multicolumn{12}{|c|}{ Materi } \\
\hline & \multicolumn{3}{|c|}{ Geometri } & \multicolumn{3}{|c|}{ Teori Peluang } & \multicolumn{3}{|c|}{ Aljabar } & \multicolumn{3}{|c|}{ Kalkulus } \\
\hline & Soal 1 & Soal 2 & Soal 3 & Soal 1 & Soal 2 & Soal 3 & Soal 1 & Soal 2 & Soal 3 & Soal 1 & Soal 2 & Soal 3 \\
\hline S1 & $\sqrt{1}$ & $\sqrt{1}$ & - & $\sqrt{ }$ & $\sqrt{ }$ & - & $\sqrt{ }$ & $\sqrt{ }$ & $\sqrt{ }$ & $\sqrt{ }$ & $\sqrt{ }$ & $\sqrt{ }$ \\
\hline S2 & $\sqrt{ }$ & $\sqrt{ }$ & - & $\sqrt{v}$ & $\sqrt{ }$ & $\sqrt{ }$ & - & $\sqrt{ }$ & $\sqrt{ }$ & $\sqrt{ }$ & $\sqrt{\mathrm{V}}$ & $\sqrt{ }$ \\
\hline S3 & $\sqrt{ }$ & $\sqrt{ }$ & $\sqrt{ }$ & $\sqrt{ }$ & $\sqrt{ }$ & $\sqrt{ }$ & $\sqrt{ }$ & $\sqrt{ }$ & $\sqrt{ }$ & $\sqrt{ }$ & $\sqrt{ }$ & $\sqrt{ }$ \\
\hline S4 & - & $\sqrt{ }$ & $\sqrt{ }$ & $\sqrt{ }$ & - & $\sqrt{ }$ & $\sqrt{ }$ & $\sqrt{ }$ & $\sqrt{ }$ & $\sqrt{ }$ & - & - \\
\hline S5 & - & $\sqrt{ }$ & $\sqrt{ }$ & $\sqrt{ }$ & - & $\sqrt{ }$ & $\sqrt{ }$ & $\sqrt{ }$ & $\sqrt{ }$ & $\sqrt{ }$ & - & $\sqrt{ }$ \\
\hline \multirow{2}{*}{ Total } & 3 & 5 & 3 & 5 & 3 & 4 & 4 & 5 & 5 & 5 & 3 & 4 \\
\hline & \multicolumn{3}{|c|}{16} & \multicolumn{3}{|c|}{12} & \multicolumn{3}{|c|}{14} & \multicolumn{3}{|c|}{12} \\
\hline
\end{tabular}

\section{HASIL DAN PEMBAHASAN}

Miskonsepsi pada penelitian ini diperoleh dari hasil tes dan wawancara. Tes dilakukan untuk mengungkap bagaimana miskonsepsi yang terjadi pada mahasiswa. Soal tes terdiri dari empat materi inti matematika yaitu geometri, teori peluang, aljabar dan kalkulus. Masing-masing materi tersebut terdiri dari tiga soal uraian. Total soal tes yang diberikan yaitu duabelas soal. Selain tes, wawancara juga dilakukan untuk memperoleh data mengenai pandangan mahasiswa terhadap miskonsepsi yang dialaminya.

Penelitian ini meninjau miskonsepsi berdasarkan indikator miskonsepsi dari Rochmad, dkk. (2018). Miskonsepsi tersebut terdiri dari : (1) konsep definsi yang tidak benar; (2) kesalahan penggunaan konsep; (3) klasifikasi yang salah terhadap contoh konsep; (4) kekeliruan interpretasi konsep dengan makna konsep, (5) kebingungan karena tidak menguasai konsep yang mendukung, dan (6) penghubungan konsep yang salah. Berikut adalah rekapitulasi terjadinya miskonsepsi dalam menjawab soal tes yang diberikan.

Pada tabel 1 terlihat bahwa pada setiap materi matematika mahasiswa mengalami miskonsepsi. Secara keseluruhan miskonsepsi paling sering terjadi pada materi geometri, tetapi tidak berbeda secara signifikan dengan materi yang lain.

Tabel 2. Jenis Miskonsepsi yang Terjadi pada Mahasiswa

\begin{tabular}{|c|c|c|c|c|c|c|c|c|c|c|c|c|c|}
\hline \multirow{3}{*}{$\begin{array}{l}\text { Jenis Miskonsepsi } \\
\text { Konsep definisi yang } \\
\text { tidak benar }\end{array}$} & \multirow{2}{*}{\multicolumn{3}{|c|}{ Geometri }} & \multirow{2}{*}{\multicolumn{3}{|c|}{$\begin{array}{l}\text { Teori Peluang } \\
\text { Soal } 1 \text { Soal } 2 \mid \text { Soal } 3 \\
\end{array}$}} & \multicolumn{3}{|c|}{ Aljabar } & \multirow{2}{*}{\multicolumn{3}{|c|}{\begin{tabular}{|c|} 
Kalkulus \\
Soald
\end{tabular}}} & \multirow{3}{*}{\begin{tabular}{|c|} 
Total \\
8 \\
\end{tabular}} \\
\hline & Soal & & Soal 3 & & & & Soal 1 & & Soal & & & & \\
\hline & & & 1 & 2 & & 1 & 1 & & & 1 & & 2 & \\
\hline $\begin{array}{l}\text { Kesalahan } \\
\text { penggunaan konsep }\end{array}$ & 1 & & & & & 2 & & 2 & & 2 & 1 & & 8 \\
\hline $\begin{array}{l}\text { Klasifikasi yang salah } \\
\text { terhadap contoh } \\
\text { konsep }\end{array}$ & & & & & & & & & & & & 1 & 1 \\
\hline $\begin{array}{l}\text { Kekeliruan } \\
\text { interpretasi konsep } \\
\text { dengan makna konsep }\end{array}$ & & 1 & & & & & & & 1 & & & & 2 \\
\hline $\begin{array}{l}\text { Kebingungan karena } \\
\text { tidak menguasai } \\
\text { konsep yang } \\
\text { mendukung }\end{array}$ & 2 & 3 & 2 & 1 & 3 & 1 & 3 & 3 & 4 & 2 & 2 & 2 & 28 \\
\hline $\begin{array}{l}\text { Penghubungan } \\
\text { konsed vang salah }\end{array}$ & & 1 & & 2 & & & & & & & & & 3 \\
\hline
\end{tabular}

Pada tabel di atas terlihat keseluruhan jenis miskonsepsi terjadi pada mahasiswa. Miskonsepsi yang paling sering terjadi yaitu kebingungan karena tidak menguasai konsep yang mendukung. Jenis miskonsepsi ini memiliki perbedaan yang sangat signifikan dibanding jenis miskonsepsi lainnya. Kebingungan mahasiswa dalam memahami konsep yang mendukung menjadi kendala terbesar mahasiswa dalam menjawab soal tes. Terdapat beberapa soal yang tidak dijawab mahasiswa karena mengalami kebingungan. Selain itu, terdapat pula mahasiswa yang menjawab dengan asal-asalan dan tidak tuntas dikarenakan tidak memahami konsep tersebut. Dengan demikian, jenis miskonsepsi ini perlu mendapat perhatian lebih untuk dicari solusinya. Salah satu terdapat dalam pengerjaan soal berikut oleh S3

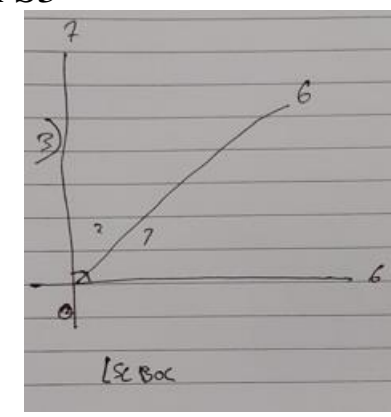

Gambar 1. Jawaban Soal Geometri oleh S3

Pada soal materi geometri, diminta untuk mencari besar sudut jika diketahui sudutsudut tersebut terhubung dalam sudut berpenyiku. Konsep yang digunakan untuk menjawab soal ini adalah konsep jumlah sudut berpenyiku. Konsep tersebut menyatakan bahwa jumlah sudut-sudut dalam sudut berpenyikut yaitu $90^{\circ}$. Tetapi S3 tidak menggunakan konsep tersebut untuk menjawab soal inial tersebut menandakan S5 mengalami kebingungan karena tidak memahami konsep yang mendukung. Dampak dari hal tersebut adalah S3 tidak mampu menjawab soal dengan lengkap dan benar.

Selain itu, jenis miskonsepsi ini juga terjadi pada S4. Perhatikan gambar berikut.

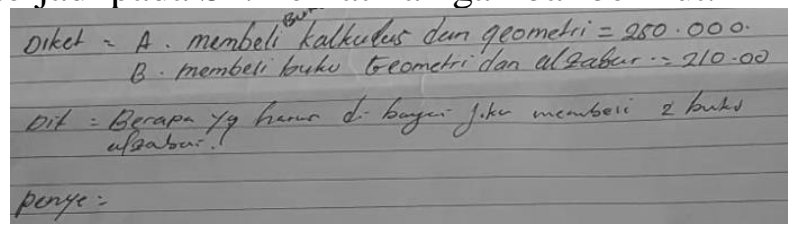

Gambar 2. Jawaban Soal Aljabar oleh S4 
Pada gambar di atas terlihat bahwa S4 hanya menuliskan aspek yang diketahui dan ditanya. Pada bagian penyelesaian, S4 tidak mampu menemukan solusi dari masalah yang diberikan. Hal ini menandakan bahwa S4 mengalami kebingungan karena tidak menguasai konsep yang mendukung.

Selain jenis miskonsepsi tersebut, jenis miskonsepsi yang juga terjadi adalah konsep definisi yang tidak benar. Hal ini terjadi karena kesalahan dalam mendefinisikan suatu konsep. Perhatikan gambar berikut.

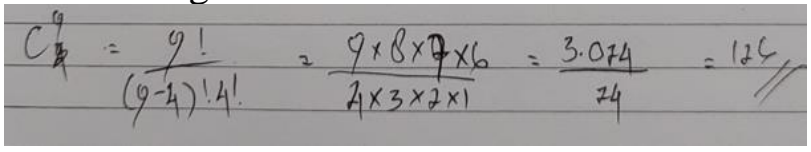

Gambar 3. Jawaban Soal Teori Peluang oleh S1

Pada soal tersebut, mahasiswa diminta mencari peluang kejadian muncul mata dadu berjumlah 4 dan kejadian muncul mata dadu berjumlah 9 dari dua buah dadu yang dilempar secara bersamaan. Untuk menjawab soal tersebut digunakan konsep peluang yang merupakan perbandingan banyaknya kejadian dan banyaknya sampel. S1 mengalami kekeliruan dalam mendefinisikan konsep tersebut sehingga $\mathrm{S} 1$ tidak menjawab dengan menggunakan konsep yang benar. Terlihat jelas pada gambar bahwa S1 menggunakan konsep kombinasi, bukan peluang.

Pada kasus S1 seperti pada hasil analisis diatas bahwa subjek tidak mampu membedakan antara konsep peluang dan kombinasi, sehingga terjadi kesalahan dalam menerapkan konsep yang tepat pada penyelesaian masalah. Hal ini dikonfirmasi oleh $\mathrm{S} 1$ seperti yang ditunjukan pada transkrip wawancara berikut.

$P \quad$ : kenapa saudara memilih rumus ini untuk pemecahan masalahnya?

S1 : Saya bingung pak, rumusnya miripmirip.

$P \quad$ : Apakah menurut saudara, konsep yang saudara itu sudah tepat?

S1 : Menurut saya sudah tepat pak.

Dari beberapa wawancara diatas menunjukan bahwa kesalahan yang terjadi karena kurangnya pemahaman siswa pada konsep dari materi, sehingga kurangnya pemahan tersebut mengakibatkan mahasiswa menerapkan konsep yang keliru pada pemecahan masalah matematika. Jenis miskonsepsi ini juga terjadi pada S4. Perhatikan gambar berikut.

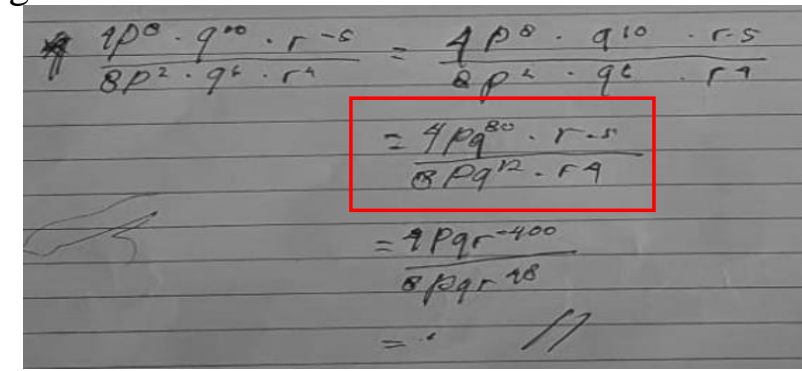

Gambar 4. Jawaban Soal Aljabar oleh S4

S4 keliru dalam mendefinisikan konsep perkalian bilangan eksponen. Berdasaran konsep perkalian bilangan eksponen, $p^{8} \times$ $q^{10}=p^{8} q^{10}$. S4 memberikan jawaban yang keliru karena mengalikan kedua eksponennya. Hal ini bertentangan dengan definisi konsep perkalian dua bilangan eksponen.

Jenis miskonsepsi lainnya yaitu kesalahan penggunaan konsep. Miskonsepsi ini juga sering terjadi pada mahasiswa. Perhatikan gambar berikut.

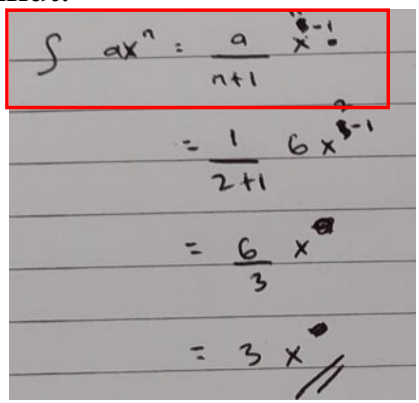

Gambar 5. Jawaban Soal Kalkulus oleh S2

Pada gambar terlihat bahwa S2 mengalami kekeliruan penggunaan konsep integral. Rumus integral yang benar seharusnya berpangkat $n+1$ bukan $n-1$. S2 juga tidak memahami penggunaan rumus integral dengan baik. Setelah dikonfirmasi langsung pada subjek melalui wawancara S2 menyadari bahwa dia telah melakukan kesalahan dalam melakukan pengitungan. Berikut transkrip wawancara S2 dengan $\mathrm{S} 2$.

$P$ : Di lembar jawaban saudara bahwa nol dibagi dua adalah tidak terhingga, apakah menurut saudara hasil penghitungan saudara sudah benar?

S4 : Maaf pak, sebenarnya jawaban itu keliru, seharusnya hasilnya adalah nol. 
$P$ : Apakah menurut saudara, konsep yang saudara gunakan itu sudah tepat?.

S4: Menurut saya sudah tepat pak, hanya perhitungannya saja yang salah.

Miskonsepsi ini juga terjadi pada S4. Perhatikan gambar berikut.

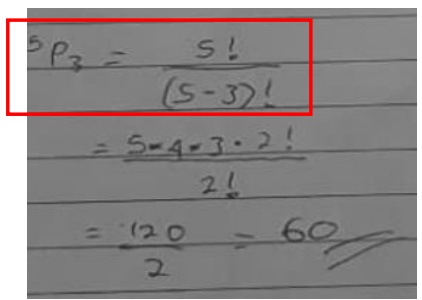

Gambar 6. Jawaban Soal Teori Peluang oleh S4

Miskonsepsi terjadi karena penggunaan konsep yang salah. Konsep yang tepat untuk memecahkan masalah tersebut adalah konsep kombinasi, bukan permutasi. Hal ini menandakan bahwa S4 keliru dalam menggunakan konsep untuk memecahkan suatu masalah.

Kesalahan konsep seperti yang ditunjukan pada hasil analisis jawaban mahasiswa diatas terjadi karena subjek memang tidak memahami konsep apa yang tepat untuk menyelesaikan masalah yang diajukan. Wawancara terhadap beberapa subjek menunujukan bahwa siswa tidak yakin telah menggunakan konsep yang tepat dalam pemecahan masalah, seperti ditunjukan pada transkrip wawancara berikut:

$P$ : Kenapa saudara memilih menggunakan konsep itu untuk menyelesaikan soal?.

S4: Saya memilih langkah tersebut karena cara itu kebih mudah dan mempercepat menyelesaikan soal.

$P$ : Apakah menurut saudara konsep itu sudah tepat?.

S4: Saya tidak yakin pak, tetapi menurut saya itu sudah tepat.

Jenis miskonsepsi berikutnya yaitu penghubungan konsep yang salah. Perhatikan gambar berikut.

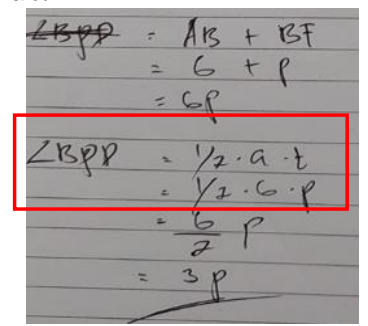

Gambar 7. Jawaban Soal Geometri oleh S1
Miskonsepsi ini terjadi karena kesalahan penghubungan konsep. Pada soal tersebut ditanyakan luas sudut, tetapi S1 justru menghubungkan dengan rumus luas segitiga. Jenis miskonsepsi ini juga terjadi pada S4.

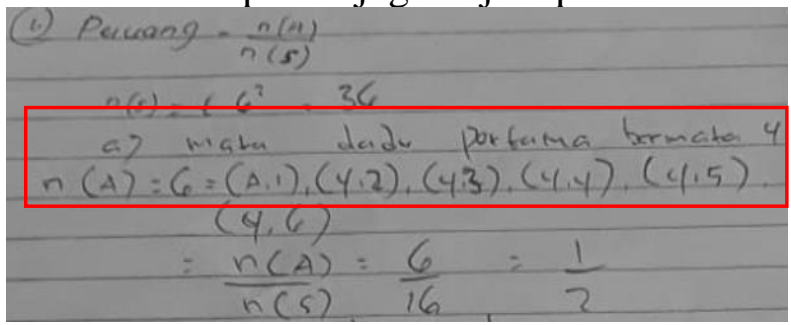

Gambar 8. Jawaban Soal Teori Peluang oleh S4

Miskonsepsi ini terjadi karena kesalahan dalam menghubungkan konsep dadu bermata 4. Dadu bermata 4 berarti jika jumlah mata dadu pada kedua dadu dijumlahkan maka akan menghasilkan 4. Tetapi S4 memahami hal tersebut dengan keliru. S4 menganggap bahwa dadu bermata 4 adalah yang memiliki mata 4 pada salah satu maupun kedua dadu.

Jenis miskonsepsi lainnya yaitu kekeliruan interpretasi konsep dengan makna konsep. Perhatikan gambar berikut.

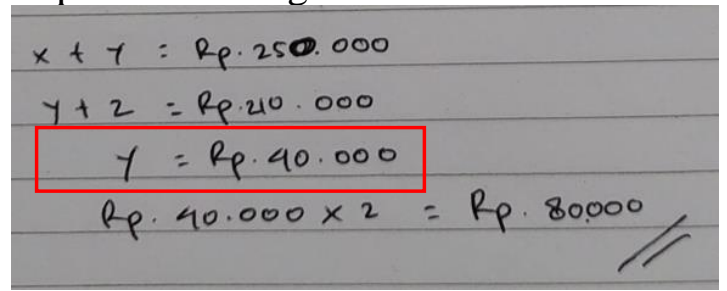

Gambar 9. Jawaban Soal Aljabar oleh S2

Miskonsepsi terjadi karena S2 keliru dalam interpretasi konsep eliminasi dan substitusi dalam persamaan linier. S2 tidak melakukan eliminasi dan subtitusi secara sistematis dan tepat. Miskonsepsi ini juga dialami oleh S4. Perhatikan gambar berikut.

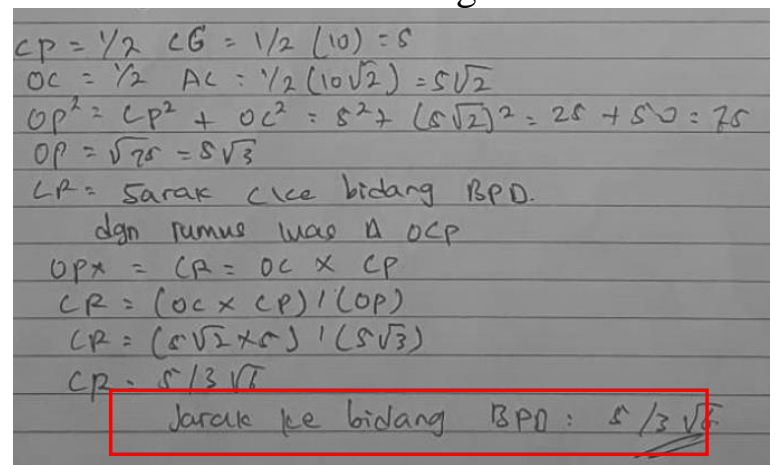

Gambar 10. Jawaban Soal Geometri oleh S4

Miskonsepsi terjadi karena kekeliruan interpretasi konsep besar sudut. Hal ini 
menjadikan S4 tidak menjawab sesuai yang diminta yaitu mencari besar sudut. S4 justru mencari jarak ke bidang.

Jenis miskonsepsi yang terakhir yaitu klasifikasi yang salah terhadap contoh konsep. Miskonsepsi ini hanya dialami oleh S2. Perhatikan gambar berikut.

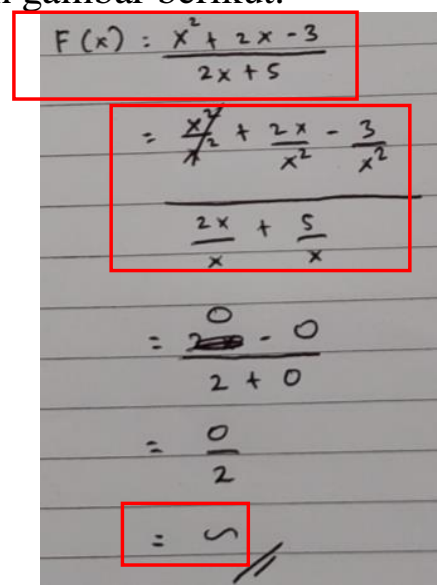

Gambar 11. Jawaban Soal Aljabar oleh S2

Terdapat 2 miskonsepsi pada pengerjaan soal ini. Miskonsepsi yang pertama yaitu konsep definisi yang tidak benar. Hal ini tampak pada gambar dimana S2 tidak menggunakan notasi penulisan limit yang benar. Selain juga terlihat pada pemahaman konsep yang keliru dimana $\frac{0}{2}$ harusnya menghasilkan 0 bukan $\sim$. Miskonsepsi yang kedua yaitu klasifikasi yang salah terhadap contoh konsep. Pada soal diminta mencari nilai limit dengan metode subtitusi, tetapi S2 justru menggunakan metode membagi dengan suku yang memiliki pangkat tertinggi. Hal ini menandakan S2 mengalami kesalahan dalam klasifikasi contoh konsep subtitusi dan membagi dengan suku yang memiliki pangkat tertinggi.

\section{KESIMPULAN}

Secara keseluruhan miskonsepsi paling sering terjadi pada materi geometri, tetapi tidak berbeda secara signifikan dengan materi yang lain. Jenis miskonsepsi yang paling sering dialami mahasiswa yaitu kebingungan karena tidak menguasai konsep yang mendukung. Miskonsepsi yang paling jarang dialami mahasiswa yaitu klasifikasi yang salah terhadap contoh konsep.

\section{SARAN}

Peneliti selanjutnya diharapkan dapat meneliti tentang faktor yang melatarbelakangi terjadinya miskonsepsi. Hal ini sangat penting agar kita dapat mengetahui hal apa yang dapat menyebabkan miskonsepsi serta mencari solusinya.

\section{UCAPAN TERIMA KASIH}

Ucapan terima kasih peneliti sampaikan kepada Kementrian Pendidikan dan Kebudayaan Republik Indonesia yang telah memberikan dana hibah penelititian, sehingga peneliti dapat menyelesaikan penelitian ini dengan tepat waktu. Peneliti juga mengucapkan terima kasih kepada pihak-pihak yang telah berkontribusi dalam penelitian ini sehingga banyak kendala dalam penelitian dapat terselesaikan

\section{DAFTAR PUSTAKA}

Al-Khateeb, M. A. (2016). The Extent of Mathematics Teacher's Awareness of Their Students' Misconceptions in Learning Geometrical Concepts in the Intermediate Education Stage. Eur. Sci. J., 12(31), 357-372. https://doi.org/10.19044/esj.2016.v12n $31 \mathrm{p} 357$

Astuty, E. (2015). Implementation Analysis of Lecturer 's Pedagogical Competence on Student 's Academic Achievement. J. Manag. Res., 7(2), 152-168.

Biber, C., Tuna, A., \& Korkmaz, S. (2013). The Mistakes and the Misconceptions of the Eighth_Grade Students on the Subject of Angles. Eur. J. Sci. Math. Educ., 87(4), 297-298.

C. S, B. M., \& S.M, W. (2018). "Contextual Approach using VBA Learning Media to Improve Students' Mathematical Displacement and Disposition Ability.

Campbell, L., \& Campbell, B. (2008). Mindful Learning: 101 Proven Strategies for Student and Teacher Success. Corwin Press.

Gillian, J. A. (1990). Contemporary Abstract Algebra (2nd ed). Heath and Company.

Kharis, M., Agoestanto, A., \& Zuhair, M. (2018). Misconception as a Critical and Creative Thinking Inhibitor for Mathematics Education Students. Unnes J. Math. Educ., 7(1), 57-62. https://doi.org/10.15294/ujme.v7i1.180 
78

Mohyuddin, R. G., \& Khalil, U. (2016). Misconceptions of Students in Learning Mathematics at Primary Level. Bull. Educ. Res., 38(1), 133162.

Mtetwa, D. K., Mudehwe, L., \& Munyira, S. (2011). Learning Mathematics for Personal Understanding and Productions: A Viewpoint. Pythagoras, $72,50-62$.

Naseer, M. S. (2015). Analysis of Students' Errors and Misconceptions in PreUniversity Mathematics Courses. 1st International Conference on Teaching \& Learning (ICTL), 34-39.

Ndemo, Z., \& Mtetwa, D. K. (2015). Negotiating the Transition from Secondary to Undergraduate Mathematics: Reflection by some Zimbabwean Students. Middle East. African J. Educ. Res., 14, 67-78.

Ojose, B. (2015). Students' Misconceptions in Mathematics: Analysis of Remedies and What Research Says. J. Sch. Math., 72, 67-78.

Ozerem, A. (2012). Misconceptions in Geometry and Suggested Solutions for Seventh Grade Students. Int. J. New Trends Arts, Sport. Sci. Educ., 1(4), 23-35.

https://doi.org/doi.org/10.1016/j.sbspro .2012.09.557.

Rakes, C. R. (2010). Misconceptions in Rational Numbers, Probability, Algebra, and Geometry. In University of Louisville's Institutional Repository.

Rochmad, Kharis, M., Agoestanto, A., Zahid, M. Z., \& Mashuri. (2018). Misconception as a critical and creative thinking inhibitor for mathematics education students. Unnes Journal of Mathematics Education, 7(1), 57-62. https://doi.org/10.15294/ujme.v7i1.180 78

Roselizawati, H., Sarwadi, H., \& Shahrill, M. (2014). 'Understanding Students' Mathematical Errors and Misconceptions: The Case of Year 11 Repeating Students. Math. Educ.
Trends Res., 2014, 1-10. https://doi.org/10.5899/2014/metr00051

Sarwadi, R., \& Shahrill, M. (2014). Understanding Students` Errors and Misconceptions : The Case of Year 11 Repeating Students. Math. Educ. Trends Res., 1-10.

Senemoğlu, N. (2013). Gelişim, öğrenme ve ögretim (23rd ed). Yargı Yayınevi.

Svandova, K. (2014). Secondary School Students Misconceptions about Photosynthesis and Plant Respiration : Preliminary Results. J. Math. Sci. Technol. Educ., 10(59-67).

T, T., \& E.C.M, A. (2019). Analysis of Students' Errors in Solving Probability based on Newman's Error Analysis. $J$. Phys. Conf. Ser.

Welder, R. M. (2012). Improving Algebra Preparation: Implications from Research on Student Misconceptions and Difficulties. Sch. Sci. Math., 112(4), 255-264.

Winarso, W., \& Toheri, T. (2017). A Case Study of Misconceptions Students in the Learning of Mathematics; The Concept Limit Function in High School. J. Ris. Pendidik. Mat., 4(1), 120-127.

Woolfolk, A., \& Margetts, K. (2013). Educational Psychology. Educational Psychology.

Zahid, M. Z., \& Sujadi, I. (2017). Pembentukan Faktorisasi Aljabar Siswa Berkemampuan Tinggi. Kreano, $J$. Mat. Kreat., 8(1), 94-100. 